\title{
PERLINDUNGAN KONSUMEN DARI IKLAN SABUN YANG MENYESATKAN KONSUMEN
}

\author{
MOH. ZAINOL ARIEF \\ Dosen Fakultas Hukum Universitas Wiraraja Sumenep \\ sobarchamim@gmail.com
}

\begin{abstract}
ABSTRAK
Masalah kemiskinan sebenarnya bukanlah masalah baru dalam sejarah peradaban manusia. Sejak dahulu, berbagai agama danaliran filsafat mencoba memecahkannya untuk menghindari penderitaan kaum fakir, akan tetapi masing-masing memiliki sikap yang berlainan terhadap kemiskinan. Kemiskinan sendiri telah menjadi salah satu penyakit sosial yang ada di Indonesia dan menjadi program pemerintah untuk mengentaskannya. Rumusan masalah penelitian ini yang pertama Bagaiman mekanisme penyaluran zakat melalui Mobile-Zakat sudah sesuai dengan ketentuan Undang-Undang Nomor 38 Tahun 1999 Tentang Pengelolaan Zakat dan Apakah pembayaran zakat melalui melalui Mobile Zakat dapat dipertanggung jawabkan dalam pendistribusiannya.

Untuk mengetahui dan menganalisa mekanisme penyaluran zakat melalui Mobile-Zakat sudah sesuai dengan ketentuan Undang-Undang Nomor 38 Tahun 1999 Tentang Pengelolaan Zakat dan Untuk mengetahui dan menganalisa pembayaran zakat melalui Mobile Zakat dapat dipertanggung jawabkan dalam pendistribusiannya.
\end{abstract}

Kata kunci: Perlindungan Konsumen Terhadap Iklan Sabun.

\section{A. PENDAHULUAN}

Pembangunan nasional bertujuan untuk mewujudkan suatu masyarakat adil dan makmur yang merata, baik materiil maupun spiritual dalam era demokrasi ekonomi berdasarkan Pancasila dan Undang-Undang Dasar 1945. Hakikat pembangunan nasional dalam arti sempit adalah pembangunan manusia Indonesia seutuhnya, sedangkan dalam arti luas pembangunan nasional adalah pembangunan masyarakat Indonesia seluruhnya. Implementasi pembangunan nasional harus dapat dirasakan oleh seluruh masyarakat di tanah air, tidak hanya sebagian atau golongan tertentu saja sebagai suatu perbaikan taraf hidup menuju ke arah yang lebih maju.

Pembangunan nasional dilaksanakan secara berkesinambungan untuk meningkatkan kemampuan nasional setidaknya setaraf dengan bangsa lain. Peningkatan pembangunan nasional ditandai dengan perkembangan teknologi dan kemajuan industri. Sektor industri merupakan faktor utama pendukung peningkatan pembangunan nasional setelah sektor pertanian. Sektor industri sebagai penyumbang porsi utama dalam pendapatan devisa negara pada porsi yang lebih besar dalam rangka meningkatkan pendapatan 
nasional dan penyerapan tenaga kerja dalam jumlah yang cukup banyak.

Kegiatan industri di Indonesia merupakan suatu cara pemenuhan kebutuhan masyarakat Indonesia, mengingat sifat konsumtif sebagian besar masyarakat Indonesia yang mudah menerima barang baru, baik itu untuk memenuhi kebutuhan sandang, pangan dan papan. Kenyataan tersebut tidak lepas dari perkembangan zaman dan kemajuan era globalisasi seperti sekarang ini.

Pelaku usaha sebagai pihak yang bertindak sebagai produsen sabun dalam rangka memperluas usaha sabun yang dijalankannya dapat menggunakan media iklan untuk menawarkan produk sabun hasil produksinya kepada masyarakat. Kegiatan promosi melalui pengiklanan merupakan jalur informasi mengenai barang dan/atau jasa yang ditawarkan kepada konsumen. Periklanan adalah komunikasi komersil dan nonpersonal tentang sebuah organisasi dan produk produknya yang ditransmisikan ke suatu khalayak target melalui media bersifat massal seperti televisi, radio, koran, majalah, direct mail (pengeposan langsung), reklame luar, atau kendaraan umum.

Pengertian pelaku usaha berdasarkan Pasal 1 angka 3 Undang-Undang Perlindungan Konsumen yakni: "Pelaku usaha adalah setiap orang perseorangan atau badan usaha, baik yang berbentuk badan hukum maupun bukan badan hukum yang didirikan dan berkedudukan atau melakukan kegiatan dalam wilayah hukum negara Republik
Indonesia, baik sendiri maupun bersama-sama melalui perjanjian menyelenggarakan kegiatan usaha dalam berbagai bidang ekonomi." Dalam penjelasan undang-undang, yang termasuk pelaku usaha adalah perusahaan, korporasi, BUMN, koperasi, importir, pedagang, distributor, dan lainlain. Pelaku usaha sebagaimana yang dimaksud dalam undang-undang adalah produsen sebagai penghasil barang dan/atau jasa.

Pelaku usaha dalam mempromosikan barang dan/atau jasa hasil produksinya kepada masyarakat tidak sembarangan menggunakan perusahaan periklanan. Iklan dimaksudkan untuk membangkitkan minat beli konsumen untuk menggunakan barang dan/atau jasa yang dihasilkan oleh produsen, dengan harapan produk yang diiklankan itu mengalami peningkatan dari sudut penjualannya.

Konsumen pada dasarnya tidak mengetahui sifat asli dari produk yang diiklankan. Iklan bagi konsumen merupakan sumber informasi dari produk yang akan dikonsumsi. Apabila konsumen sudah tertarik dengan iklan suatu produk, maka ketertarikan itu mendorong konsumen untuk membeli produk yang bersangkutan, karena dalam iklan disampaikan janji-janji mengenai manfaat dan kegunaan produk tersebut.

Dalam iklan, sabun yang tidak ada manfaatnya dikemas menjadi sesuatu yang bermanfaat, salah satunya adalah menjadikan kulit menjadi tanpak putih cerah alami. Kemewahan iklan sabun semakin 
menggiurkan dengan menjadikan kulit menjadi tanpak putih cerah alami. Iklan sabun dikemas sedemikian rupa dengan menampilkan tokoh-tokoh idola remaja dan anak-anak, yang membuat mereka semakin tertarik untuk mencoba coba sabun tersebut.

Upaya perlindungan konsumen di tanah air didasarkan pada sejumlah asas dan tujuan yang telah diyakini bias memberikan arahan dalam implementasinya di tingkatan praktis. Dengan adanya asas dan tujuan yang jelas, hukum perlindungan konsumen memiliki dasar pijakan yang benar-benar kuat.

Hukum perlindungan konsumen yang berlaku di Indonesia memiliki dasar hukum yang telah ditetapkan oleh pemerintah. Dengan adanya dasar hukum yang pasti, perlindungan terhadap hak-hak konsumen bisa dilakukan dengan penuh optimisme. larangan dalam penjualan secara obral / lelang Pelaku usaha dalam penjualan yang dilakukan melalui cara obral atau lelang, dilarang mengelabui / menyesatkan konsumen, antara lain :

1. menyatakan barang atau jasa tersebut seolah-olah telah memenuhi standar tertentu.

2. Tidak mengandung cacat tersembunyi.

3. Tidak berniat untuk menjual barang yang ditawarkan melainkan dengan maksud menjual barang lain.

4. Tidak menyedian barang dalam jumlah tertentu atau jumlah cukup dengan maksud menjual barang yang lain

\section{B. PEMBAHASAN}

Tujuan hukum adalah untuk menjamin kepastian dalam masyarakat, yang dengan kepastian hukum tersebut maka perlindungan hukum bagi masyarakat pun terpenuhi, perlindungan hukum dalam bentuk kepastian hukum dapat dilihat dari dua aspek, yaitu "Pertama aspek tujuan hukum yaitu untuk menciptakan kepastian hukum dan kedua aspek penegakan hukum hukum yaitu hukum berfungsi sebagai perlindungan kepentingan manusia melalui upaya penegakan hokum". Berdasarkan pendapat ini perlindungan hukum tidak akan efektif jika tidak ditunjang oleh adanya kepastian hukum yang jelas dan tegas.

Perlindungan hukum terdiri dari 2 (dua) suku kata, yaitu "perlindungan" dan "hukum", artinya perlindungan menurut hukum dan undang-undang yang berlaku. Pasal 1 ayat 3 Undang-Undang Dasar 1945 setelah Amandemen menyatakan bahwa "Negara Indonesia adalah negara hukum." Artinya segala tindakan dalam bentuk apapun harus ada pertanggungjawaban hukumnya. Setiap warga negara berhak atas perlindungan hukum yang diberikan oleh negara. Prinsip perlindungan hukum bagi rakyat Indonesia adalah prinsip pengakuan dan perlindungan terhadap harkat dan martabat manusia yang bersumber pada Pancasila. Prinsip perlindungan hukum nasional juga tercermin dalam Pembukaan Undang-Undang Dasar Negara Republik Indonesia tahun 1945, “...untuk melindungi segenap bangsa 
Indonesia dan seluruh tumpah darah Indonesia.

Dalam rangka meningkatkan harkat dan martabat konsumen perlu diiringi dengan peningkatan kesadaran, pengetahuan, kepedulian, kemampuan dan kemandirian konsumen untuk melindungi dirinya serta menumbuh kembangkan sikap dan perilaku usaha yang bertanggung jawab. Perlindungan terhadap konsumen diatur dalam UndangUndang Nomor 8 Tahun 1999 Tentang Perlindungan Konsumen (UUPK). Pasal 1 angka 1 Undang-Undang Perlindungan Konsumen menjelaskan: "Perlindungan Konsumen adalah segala upaya yang menjamin adanya kepastian hukum untuk memberi perlindungan kepada konsumen" "Perlindungan terhadap konsumen dipandang secara material maupun formal mengingat makin lajunya ilmu pengetahuan dan teknologi yang merupakan motor penggerak bagi produktivitas dan efisiensi atas barang atau jasa yang dihasilkannya dalam rangka mencapai sasaran usaha".

Perlindungan konsumen merupakan masalah kepentingan manusia, oleh karenanya menjadi harapan bagi semua bangsa di dunia untuk mewujudkannya. Mewujudkan perlindungan konsumen adalah mewujudkan hubungan berbagai dimensi yang satu sama lain mempunyai keterkaitan dan saling ketergantungan antara konsumen, pengusaha, dan pemerintah.

Prinsip dasar perlindungan konsumen adalah sesuai dengan asas yang tercantum dalam Pasal 2 Undang-Undang Perlindungan Konsumen, yakni "Perlindungan Konsumen berasaskan manfaat, keadilan, keseimbangan, keamanan dan keselamatan konsumen, serta kepastian hukum." Perlindungan hukum bagi konsumen dapat dimulai dengan pengawasan terhadap produk yang ditawarkan, mutu dan kualitas, serta ketepatan kegunaan dan manfaat produk yang bersangkutan. Kendala yang muncul dalam perlindungan konsumen di Indonesia tidak hanya terbatas pada rendahnya kesadaran konsumen akan hakhaknya yang dilanggar, tetapi persepsi sebagian besar pelaku usaha bahwa memberikan perlindungan hukum terhadap konsumen berarti mendekatkan mereka pada kerugian. Berdasarkan keadaan yang demikian, perlindungan hukum bagi konsumen tidak hanya terpaku pada UndangUndang saja, melainkan oleh perangkat hukum yang mampu memberikan perlindungan kepada konsumen secara efektif dan komprehensif.

Hukum konsumen juga diketemukan di dalam berbagai peraturan perundangundangan yang berlaku, yang juga memuat berbagai kaidah yang menyangkut hubungan dan masalah konsumen. Sekalipun peraturan perundangundangan tersebut tidak khusus diterbitkan untuk konsumen, setidak-tidaknya dapat dijadikan dasar bagi perlindungan konsumen.

Jadi berdasarkan uraian di atas dapat ditarik kesimpulan bahwa iklan menyesatkan adalah suatu berita pesanan yang mendorong, 
membujuk khalayak ramai mengenai barang atau jasa yang dijual, dipasang di dalam media massa seperti surat kabar atau majalah, namun isi berita yang disajikan belum diketahui kebenarannya yang pasti sehingga dapat merugikan konsumen. Dari pengertian iklan menyesatkan di atas, maka timbul pertanyaan, konsumen yang mana dirugikan akibat iklan yang menyesatkan tersebut.

Sebelum membahas tentang siapa pihak yang dirugikan akibat iklan yang menyesatkan tersebut. Tentunya perlu diketahui terlebih dahulu pengertian konsumen secara umum. Tujuan penggunaan barang atau jasa itu nanti menentukan termasuk konsumen mana pengguna tersebut.

Di dalam Kitab Undang-Undang Hukum Perdata (selanjutnya disebut KUH-Perdata) tidak ditemukan istilah konsumen, tapi berdasarkan pendirian Mahkamah Agung terdapat beberapa istilah yang perlu diperhatikan, karena istilah ini agak dekat dengan istilah konsumen. Istilah-istilah tersebut antara lain "pembeli" (Pasal 1460, Pasal 1513, jo 1457 KUH-Perdata), "penyewa" (Pasal 1550, jo Pasal 1548 KUHPerdata), "penerima hibah" (Pasal 1744 KUHPerdata) dan sebagainya. Sedangkan di dalam Kitab Undang-Undang Hukum Dagang (selanjutnya disebut KUHD) ditemukan istilah tertanggung (Pasal 246), "penumpang” (Pasal 393, Pasal 394 jo Pasal 341).

Pembeli barang dan/atau jasa, penyewa, penerima hibah, peminjam pakai, peminjam, tertanggung, atau penumpang pada satu sisi dapat merupakan konsumen (akhir) tetapi pada sisi lain dapat pula diartikan sebagai pelaku usaha. Kesemua mereka itu sekalipun pembeli misalnya, tidak semata-mata sebagai konsumen akhir (untuk non-komersial) atau untuk kepentingan diri sendiri, keluarga atau rumah tangga masing-masing tersebut. Konsumen dalam hal ini merupakan individu atau kaum rumah tangga yang melakukan pembelian untuk tujuan penggunaan personal, produsen adalah individu atau organisasi yang melakukan pembelian untuk tujuan produksi.

Menurut AZ Nasution bahwa hukum perlindungan konsumen merupakan bagian khusus dari hukum konsumen, yaitu keseluruhan asas-asas dan kaidah-kaidah yang mengatur dan melindungi konsumen dan hubungan dan masalah penyediaan dan penggunaan produk (barang dan/atau jasa) konsumen antara penyedia dan penggunanya, dalam kehidupan bermasyarakat. Sedangkan hukum konsumen adalah keseluruhan asasasas dan kaidah-kaidah yang mengatur hubungan dan masalah penyediaan dan penggunaan produk (barang/atau jasa) antara penyedia dan penggunanya, dalam kehidupan bermasyarakat. Pada Pasal 1 UUPK dimaksud dengan Perlindungan konsumen adalah segala upaya yang menjamin adanya kepastian hukum untuk memberi perlindungan kepada konsumen. Sedangkan konsumen yang dilindungi adalah setiap orang pemakai barang dan/atau jasa yang tersedia dalam masyarakat, baik bagi kepentingan diri 
sendiri, keluarga, orang lain, maupun makhluk hidup lain dan tidak untuk diperdagangkan.

Setelah diketahui tentang apa itu iklan yang menyesatkan dan siapa yang dirugikan, maka timbul pertanyaan baru, bagaimana upaya konsumen untuk mempertahankan hakhaknya yang telah dirugikan akibat iklan yang menyesatkan tersebut dan bagaimana perlundungan Undang-undang Perlndungan Konsumen melindungi hak-hak konsumen yang telah dirugikan tersebut. Undang-undang Perlindungan Konsumen isinya adalah mengatur prilaku pelaku usaha dengan tujuan agar konsumen terlindungi. Salah satunya melindungi konsumen atas iklan yang menyesatkan konsumen.

Permasalahan akan timbul apabila pelaku usaha untuk mendapatkan keuntungan yang besar membuat iklan yang bertentangan dengan asas-asas yang terdapat dalam kode etik periklanan. untuk itu pelaku usaha periklanan harus mempertanggung jawabkan atas iklan yang dibuatnya untuk menawarkan barang dan/jasanya kepada konsumen. Hal ini dilakukan untuk melindungi konsumen dari tindakan-tindakan curang yang dilakukan pelaku usaha. Mengenai pertanggungjawaban ini terdapat undang-undang yang mengatur mengenai periklanan walupun tidak secara khusus.

Perlindungan hukum bagi konsumen atas iklan yang menyesatkan dalam Undangundang Perlindungan Konsumen, yaitu dengan adanya pengaturan dalam Bab III Pasal 4 sampai dengan Pasal 7 mengenai hak- hak dan kewajiban konsumen dan juga hak dan kewajiban pelaku usaha yang telah disebutkan pada bab sebelumnya. Dalam Bab IV merupakan upaya Undang-undang Perlindungan Konsumen untuk melindungi konsumen, yaitu terdapatnya aturan mengenai larangan-larangan bagi pelaku usaha yang mengiklankan produknya larangan-larangan tersebut dapat dilihat dalam Pasal-Pasal 9s/d17.

Dalam Pasal 20 Undang-undang Perlindungan Konsumen juga diatur mengenai tanggung jawab pelaku usaha periklanan yang telah dijelaskan sebelumnya. Hal ini untuk melindungi konsumen dari pelaku usaha periklanan yang curang.

Sistem pembuktian terbalik sebagaimana yang dikatakan dalam Pasal 22 dan Pasal 28 UUPK juga merupakan upaya untuk melindungi konsumen dari pelaku usaha yang curang. Begitu pula adanya pengaturan mengenai tanggung jawab pelaku usaha yang terdapat dalam Pasal 19 UUPK.

Bentuk lainnya untuk melindungi konsumen, yaitu dengan dibentuknya Badan Perlindungan Konsumen Nasional (BPKN) yang diatur pada Bab VIII Undang-undang Perlindungan Konsumen mulai dari Pasal 31 sampai dengan Pasal 43. Salah satu tugas BPKN adalah menerima pengaduan tentang perlindungan konsumen dari masyarakat lembaga perlindungan konsumen swadaya masyarakat atau pelaku usaha.

Undang-undang Perlindungan Konsumen dalam rangka melindungi konsumen selain 
lembaga yang resmi dibentuk oleh pemerintah, dalam Bab IX Pasal 44 memungkinkan di bentuknya Lembaga Perlindungan Konsumen Swadaya Masyarakat (LPKSM). LPKSM ini mempunyai tugas salah satunya adalah membantu konsumen dalam memperjuangkan hak-haknya, termasuk menerima keluhan atau pengaduan dari konsumen seperti YLKI dan YPKB.

Iklan yang menyesatkan atau yang tidak sesuai dengan kebenarannya merugikan konsumen, sehingga menimbulkan sengketa antara konsumen yang menuntut haknya terhadap pelaku usaha yang mengiklankan produk yang dijualnya. Mengenai penyelesaian sengketa ini diatur dalam Bab X tentang penyelesaian konsumen. Upayaupaya penyelesaian sengketa dapat ditempuh dengan cara yang terdapat dalam Pasal 45 ayat (2) yaitu penyelesaian sengketa dapat ditempuh melalui pengadilan atau di luar pengadilan berdasarkan pilihan sukarela para pihak yang bersengketa.

\section{PENUTUP}

Perlindungan hukum terhadap konsumen yang telah dirugikan terkait dengan iklan maka konsumen berhak mengajukan tuntutan sesuai dengan Undang-Undang No. 8 Tahun 1999 tentang Perlindungan Konsumen terhadap pelaku usaha yang mana dalam hal ini konsumen bisa melakukan upaya penyelesaian sengeketa menurut UUPK
(Undang-Undang

Perlindungan

Konsumen ) dapat dilakukan dengan cara penyelesaian di luar pengadilan, yaitu dengan penyelesaian secara damai, penyelesaian yang dilakukan oleh kedua belah pihak yang bersengketa (pelaku usaha dan konsumen) tanpa melalui pengadilan atau Badan Penyelesaian Sengketa Konsumen, dan tidak bertentangan dengan Undang-undang Perlindungan Konsumen ini, dan penyelesaian melalui Badan Penyelesaian Sengketa Konsumen (BPSK) serta penyelesaian melalui pengadilan sesuai dengan undang-undang tentang lembaga peradilan.

\section{DAFTAR PUSTAKA}

Didin Agus Brotosusilo, dalam Celina Tri Siwi Kristiyanti, 2009. Hukum Perlindungan Konsumen, Sinar Grafika, Jakarta.

Celina Tri Siwi Kristiyanti, 2009. Hukum Perlindungan Konsumen, Sinar Grafika, Jakarta.

Man Suparman Sastrawidjaja, dalam Susanti Adi Nugroho, 2008, Proses Penyelesaian Sengketa Konsumen Ditinjau dari Hukum Acara Serta Kendala Implementasinya, Kencana, Jakarta.

Philipus M. Hadjon, 2007, Perlindungan Hukum bagi Rakyat Indonesia, Balai Pustaka, Surabaya.

Sofie, Yusuf, 2003, Perlindungan Konsumen dan Istrumen-Instrumen Hukumnya, Bandung, Citra Aditya Bakti. 


\section{FAKULTAS HUKUM UNIVERSITAS WIRARAJA SUMENEP - MADURA}

Kitab Undang-Undang Hukum Perdata.

Undang-Undang Nomor 8 Tahun 1999 tentang Perlindungan Konsumen.

Undang-Undang Nomor 30 Tahun 1999 Tentang Arbitrase dan Alternatif Penyelesaian Sengketa.

Undang-Undang Nomor 40 Tahun 1999 Tentang Pers.
Undang-Undang Nomor 32 Tahun 2002 Tentang Penyiaran.

Peraturan Pemerintah Nomor 55 Tahun 1970 Tentang Radio Siaran Non Pemerintah. 